\title{
Levels of Heavy Metals and Vitamin $C$ in Deformed Thornfish Found in Thermal Waters and Effect of Vitamin $C$ on Deformation of Thornfish
}

\author{
Deng-Fwu Hwang, ${ }^{*}{ }^{1 \dagger}$ Liang-Tan Chien, ${ }^{* 1}$ Kwang-Tsao Shao, ${ }^{* 2}$ \\ and Sen-Shyong Jeng*1 \\ ${ }^{* 1}$ Department of Marine Food Science, National Taiwan Ocean University, \\ Keelung, Taiwan, R.O.C. \\ ${ }^{* 2}$ Institute of Zoology, Academia Sinica, Taipei, Taiwan, R.O.C. \\ (Received July 17, 1997)
}

\begin{abstract}
Normal and deformed thornfish Terapon jarbua were collected from waters near the outlet of a nuclear power plant in northern Taiwan from June to September 1994. The levels of vitamin C and heavy metals and the ratio of hydroxyproline/proline in the fish were analyzed. The results indicated that the levels of heavy metals $(\mathrm{Zn}, \mathrm{Cu}, \mathrm{Sn}, \mathrm{Pb}$, and $\mathrm{Cd})$ were not significantly different between normal and deformed fish. But the level of vitamin $\mathrm{C}$ and the ratio of hydroxyproline/proline in the deformed fish were lower than those of the normal fish. Thornfish were further separately cultured at 28,32 , and $36^{\circ} \mathrm{C}$, and fed a diet without vitamin C-supplement. Deformed fish appeared at $36^{\circ} \mathrm{C}$ only, but this did not occur when fish were fed a diet with vitamin $\mathrm{C}$-supplement. Therefore, deficiency in vitamin $\mathrm{C}$ might be a cause of deformed fish found in waters near the nuclear power plant.
\end{abstract}

Key words: terapon jarbua, thorn fish, vitamin C, heavy metal, deformed fish, Taiwan

Since 1993, skeletal-deformed fishes have often been captured from waters near the outlet of a nuclear plant in northern Taiwan in summer. The deformed fish included two species, thornfish Terapon jarbua and mullet Liza macrolepis. Both species inhabit warm water environments, especially in the juvenile stage of thornfish. The temperature of avoidance and mortality for thornfish are about $38^{\circ} \mathrm{C}$ and $41^{\circ} \mathrm{C}$, respectively. ${ }^{1)}$ When deformed fish appear, a number of causative agents have been suspected, such as pollutants including nucleic materials, heavy metals, organic tin, and high water temperature generated from the nuclear power plant. Based on monitoring data, ${ }^{2,3)}$ the average water temperature was usually $16^{\circ} \mathrm{C}$ in winter and $29^{\circ} \mathrm{C}$ in summer in the northern coast of Taiwan, but was often over $39^{\circ} \mathrm{C}$ in the outlet area where the deformed fishes were found. Hence, thermal impact was suspected as a causative factor of deformed fish.

Thermal impact is well known as a factor causing deficiency in vitamin $C$ (ascorbic acid) for fish. ${ }^{4,5}$ Because vitamin $C$ appears to act as a co-factor in the enzymatic hydroxylation of proline residues of the collagen of connective tissue of vertebrates to form 4-hydroxyproline residues, ${ }^{6}$ the ratio of hydroxyproline/proline in the collagen of fish will be decreased by the deficiency in vitamin

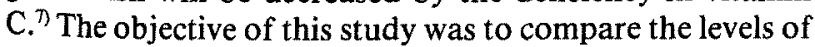
vitamin $C$ and heavy metals and the ratio of hydroxyproline/proline in the deformed and normal thornfish, and to investigate the association of fish deformation with the thermal effluent.

\section{Materials and Methods}

\section{Materials from Thermal Waters}

Eighteen specimens of deformed (body weight $11.65 \pm 3.23 \mathrm{~g}$, mean \pm S.D.) and normal $(11.63 \pm 2.56 \mathrm{~g})$ thornfish Terapon jarbua were collected from the warm waters near the outlet of a nuclear power plant in northern Taiwan from June to September 1994 using fish tackle. The fish collected were kept alive and transported to the laboratory. The specimens were immediately weighed, dissected and then divided into deformed and normal fish groups by examination of the skeleton. Two tissues, muscle and liver, were immediately analyzed for level of vitamin $\mathrm{C}$, two other tissues, skin and bone, were kept at $-20^{\circ} \mathrm{C}$ and used to determine the level of proline and hydroxyproline. Moreover, the muscle, viscera (liver removed), and bone were also analyzed for heavy metals.

\section{Materials for Laboratory Test}

Two thousand normal individuals of small thornfish (body length $0.85 \pm 0.12 \mathrm{~cm}$, body weight $0.042 \pm 0.02 \mathrm{~g}$ ) were collected by fishermen at Tamshui, Taipei. The sea water and sand $(5 \mathrm{~cm}$ depth) used in experimental aquaria were collected from the nearby effluent of a nuclear power plant. The diet was manufactured with peeled meat of thick-shell shrimp Trachy penaeus curvirostris and artificial eel feed (Fwushou brand, Taiwan). The ratio of peeled shrimp meat and eel feed was 1:1. The chemical composition of diet was as follows: moisture $45.5 \%$, ash $6.0 \%$, protein $25.2 \%$, fat $4.0 \%$, and carbohydrates $19.3 \%$. The

\footnotetext{
${ }^{\dagger}$ To whom correspondence should be addresed.
} 
measured level of vitamin $\mathrm{C}$ in both diets without and with supplement of $2,000 \mathrm{ppm}$ vitamin $\mathrm{C}$ (L-ascorbic acid form, Sigma) was $14.4 \pm 2.1 \mathrm{ppm}$ and $1894.7 \pm 82.3 \mathrm{ppm}$, respectively.

\section{Test Methodology}

The small thornfish were acclimated in several aquaria $(60 \times 58 \times 35 \mathrm{~cm})$ with closed circulating system for one week and fed the diet without vitamin C-supplement. Then fish of almost the same size were selected and divided into four groups of eight aquaria (duplicate for each group, 60 fish/aquarium). Three groups were separately cultured at $28^{\circ} \mathrm{C}, 32^{\circ} \mathrm{C}$ and $36^{\circ} \mathrm{C}$, and fed without vitamin C-supplement for 12 weeks. The last group $\left(36^{\circ} \mathrm{C}\right)$ and fed diet with $2,000 \mathrm{ppm}$ vitamin C-supplement for 12 weeks. These diets were prepared every 2 weeks and then stored at $-40^{\circ} \mathrm{C}$ until used. The fish were given the feed (dry base) at the ratio of $9 \%$ body weight daily in the first 2 weeks, then at $5 \%$ in later periods. During the culture period, the water temperature was controlled by a heating system (Model: B403-D, Firstek Scientific Co., Taiwan), and the variation of water temperature was below $1^{\circ} \mathrm{C}$. The mortality, deformity, and body weight of all fish were determined every 2 weeks, then the amount of diet given to the fish was adjusted. Among them, the deformity was judged by outward appearance of fish body.

\section{Determination of Vitamin $C$}

The fish liver and muscle were homogenized with $5 \%$ metaphosphoric acid. After centrifugation, vitamin $\mathrm{C}$ in a portion of the extract was measured by the method of Shiau and Hsu. ${ }^{8}$

\section{Extraction and Purification of Collagen}

The skin and bone were cleaned off other tissues such as scales, subcutaneous fatty tissues and muscle. The sample was homogenized with 50 volumes of $0.5 \mathrm{M}$ acetic acid in a homogenizer. Collagen was extracted and purified by the method as described previously. ${ }^{9)}$

Determination of Proline and Hydroxyproline in Collagen

Purified acid soluble collagen from the skin and bone was hydrolyzed in $6 \mathrm{~N} \mathrm{HCl}$ in a sealed tube at $130^{\circ} \mathrm{C}$ for 3 $\mathrm{hr}$. Proline and hydroxyproline in the hydrolysate were de termined by the method of Troll and Lindsley ${ }^{10)}$ and by the method of Woessner. ${ }^{11)}$

\section{Determination of Heavy Metals}

All samples were first digested by $\mathrm{H}_{2} \mathrm{SO}_{4}-\mathrm{HNO}_{3}$, then determined by a Polarized Zeeman Atomic Absorption Spectrophotometer (Hitachi $\mathrm{Z}-8100$, Japan) for $\mathrm{Cd}, \mathrm{Cu}, \mathrm{Pb}$, $\mathrm{Sn}$, and $\mathrm{Zn},{ }^{12)}$

\section{Statistical Analysis}

All data were analyzed for the different treatments by analysis of variance (ANOVA), and Duncan's new multiple range test was used to resolve the difference among treatment means. ${ }^{13)}$ A value of $P<0.05$ was used as the criterion for significant differences.

\section{Results}

The level of vitamin $C$ in the muscle and liver of thornfish collected from the nearby effluent of the nuclear power plant is shown in Fig. 1. The respective level of vitamin $C$ in the normal and deformed fish was $10.79 \pm 3.14$ $\mu \mathrm{g} / \mathrm{g}$ (mean \pm S.D.) and $8.29 \pm 2.36 \mu \mathrm{g} / \mathrm{g}$ in the muscle, and $11.43 \pm 1.71 \mu \mathrm{g} / \mathrm{g}$ and $5.71 \pm 1.50 \mu \mathrm{g} / \mathrm{g}$ in the liver. It was found that the level of vitamin $C$ in normal fish was significantly higher than that in the deformed fish $(P<0.05)$.

The ratio of hydroxyproline/proline in fish collected from the outlet area of the nuclear power plant is shown in Fig. 2. The respective ratio of hydroxyproline/proline in the normal and deformed fish was $1.63 \pm 0.15$ and $1.44 \pm 0.15$ in the skin, and $1.58 \pm 0.25$ and $1.19 \pm 0.17$ in the bone. It indicated that the ratio of hydroxyproline/proline in the skin and bone of normal fish was significantly higher than that in the deformed fish $(P<0.05)$.

The levels of heavy metals in fish collected from the out-

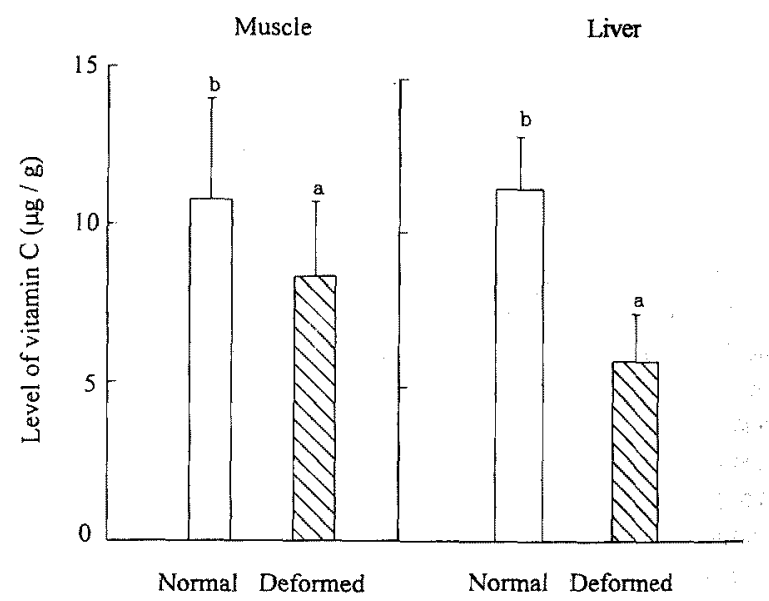

Fig. 1. The levels of vitamin $C$ in the muscle and liver of thornfish collected from the nearby effluent of the nuclear power plant. $a-b$ : Values in the figure with different superscripts are significantly different at $P<0.05$

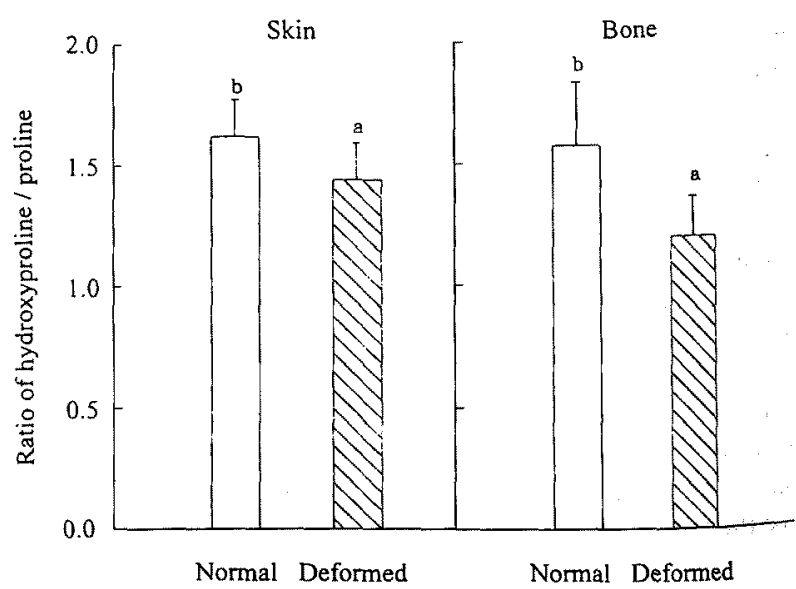

Fig. 2. Hydroxyproline/proline ratios in the skin and bone of thornfish collected from the nearby effluent of the nuclear power plant $\mathrm{a}-\mathrm{b}$ : See footnote in Fig. 1. 
Table 1. The levels of heavy metals in the normal and deformed thornfish collected from the waters near the nuclear power plant

\begin{tabular}{lccccc}
\hline & \multicolumn{5}{c}{ Levels of heavy metals (mean \pm S.D.) } \\
\cline { 2 - 6 } Sample & $\begin{array}{c}\mathrm{Zn} \\
(\mathrm{ppm})\end{array}$ & $\begin{array}{c}\mathrm{Cu} \\
(\mathrm{ppm})\end{array}$ & $\begin{array}{c}\mathrm{Sn} \\
(\mathrm{ppm})\end{array}$ & $\begin{array}{c}\mathrm{Pb} \\
(\mathrm{ppb})\end{array}$ & $\begin{array}{c}\mathrm{Cd} \\
(\mathrm{ppb})\end{array}$ \\
\hline Normal fish & & & & & \\
$\quad$ Muscle & $7.20 \pm 2.12$ & $0.94 \pm 0.14$ & $0.12 \pm 0.10$ & $<10$ & $<5$ \\
Viscera & $15.38 \pm 4.04$ & $2.79 \pm 0.96$ & $0.35 \pm 0.12$ & $<10$ & $<5$ \\
Bone & $38.26 \pm 2.09$ & $2.87 \pm 0.35$ & $0.38 \pm 0.04$ & $<10$ & $<5$ \\
\hline Deformed fish & & & & & \\
Muscle & $8.21 \pm 1.68$ & $0.88 \pm 0.11$ & $0.11 \pm 0.04$ & $<10$ & $<5$ \\
Viscera & $14.04 \pm 3.46$ & $2.50 \pm 1.15$ & $0.42 \pm 0.19$ & $<10$ & $<5$ \\
Bone & $38.24 \pm 3.48$ & $2.61 \pm 0.39$ & $0.39 \pm 0.38$ & $<10$ & $<5$ \\
\hline
\end{tabular}

let area of the nuclear power plant are shown in Table 1. Among all of the samples, the levels of $\mathrm{Pb}$ and $\mathrm{Cd}$ were not detected $(\mathrm{Pb}<10 \mathrm{ppb}, \mathrm{Cd}<5 \mathrm{ppb})$. The levels of other heavy metals $\mathrm{Zn}, \mathrm{Cu}$, and $\mathrm{Sn}$ in normal and deformed fish were not significantly different $(P>0.05)$.

In the experiment, four groups of thornfish were separately cultured in different water temperatures and fed diet with or without vitamin C-supplement for 12 weeks. It was found that the mortality of thornfish increased as the culture temperature was increased, and vitamin $\mathrm{C}$ reduced the mortality of fish (Table 2). The deformed thornfish appeared in only the $36^{\circ} \mathrm{C}$ group. The growth of thornfish separately cultured in different temperatures and fed diets with and without vitamin C-supplement for 12 weeks is shown in Fig. 3. After 12-weeks culture, the body weight of thornfish was the best in the $32^{\circ} \mathrm{C}$ group. In the $28^{\circ} \mathrm{C}$, $32^{\circ} \mathrm{C}, 36^{\circ} \mathrm{C}$, and $36^{\circ} \mathrm{C}+$ vitamin $\mathrm{C}$ groups, the respective weight gain was $2550 \pm 110 \%, 4900 \pm 190 \%, 1640 \pm 110 \%$, and $2780 \pm 130 \%$, and the respective feed conversion ratio (FCR) was $0.96 \pm 0.18,0.77 \pm 0.11,1.75 \pm 0.21$, and $1.13 \pm 0.14$. These results indicated that the growth of thornfish cultured at $32^{\circ} \mathrm{C}$ was the best.

The level of vitamin $\mathrm{C}$ in the muscle and liver of thornfish is shown in Fig. 4. It was found that the levels of vitamin $C$ in the muscle and liver of thornfish were the highest in the $36^{\circ} \mathrm{C}+$ vitamin $\mathrm{C}$ group than those in other groups. However the level of vitamin $\mathrm{C}$ in the liver of thornfish cultured at $36^{\circ} \mathrm{C}$ for 12 weeks was not different from that of other groups $(P>0.05)$, but it was significantly lower in the muscle of thornfish cultured at $36^{\circ} \mathrm{C}$ for eight weeks $(P<0.05)$. The ratios of hydroxyproline/proline in the skin and bone of thornfish are shown in Fig. 5. It was found that the ratio of hydroxyproline/proline was significantly lower in both tissues of thornfish cultured at $36^{\circ} \mathrm{C}$ for four weeks. When the diet was supplemented

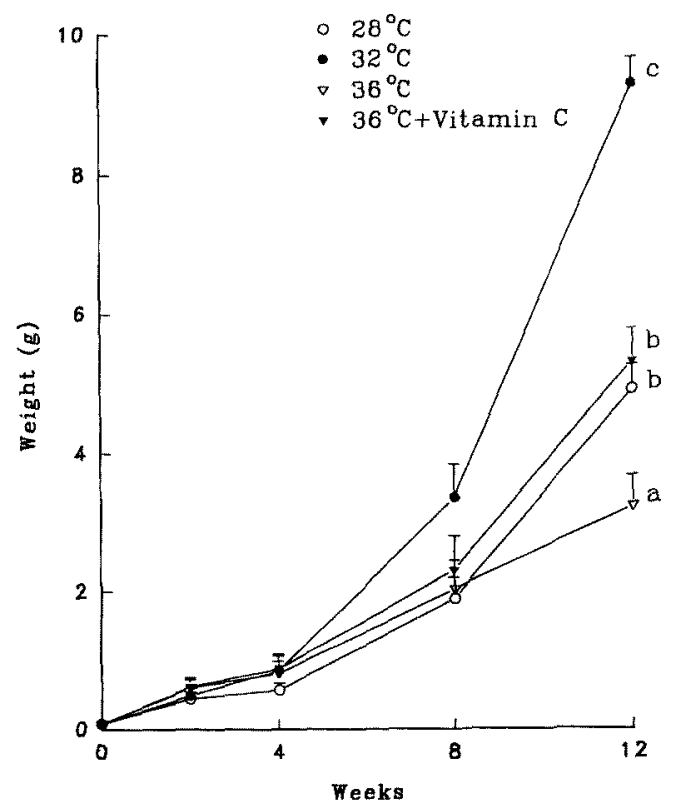

Fig. 3. The growth of thornfish separately cultured at different temperatures and fed diets with or without vitamin $\mathrm{C}$-supplement for weeks. a-c: See footnote in Fig. 1.

with high dose of vitamin $\mathrm{C}$, the ratio of hydroxyproline/ proline significantly increased.

\section{Discussion}

Although the impact of thermal effluent of nuclear power plants on the ecosystem has been discussed, ${ }^{14,15)}$ the appearance of deformed fish in outlets has not been reported so far. In this study, the level of vitamin $\mathrm{C}$ and the ratio of hydroxyproline/proline were found to be less in deformed fish than in normal fish. This means that the deficiency in vitamin $C$ was the causative factor of the skeletal deformity for thornfish. It is well known that normally collagen contains the amino acid hydroxyproline, which is obtained by conversion from the amino acid proline. In vitamin $\mathrm{C}$ deficiency, this conversion does not take place. The resulting impairment of connective tissue regeneration is suggested to be the cause of bone disorganization.6,7)

When the thornfish were cultured at different temperatures by using the sea water and sand of nearby effluent of the nuclear power plant in experimental aquaria, the deformed fish appeared at $36^{\circ} \mathrm{C}$ only, but did not occur when fishes were fed diet with vitamin $\mathrm{C}$-supplement. The level of vitamin $C$ in the muscle and the ratios of hydrox-

Table 2. Mortality and deformity of thornfish separately cultured in different temperature and fed diets with or without vitamin C-supplement for 12 weeks

\begin{tabular}{|c|c|c|c|c|c|c|c|c|}
\hline \multirow{3}{*}{ Group } & \multicolumn{4}{|c|}{ Mortality (\%) } & \multicolumn{4}{|c|}{ Deformity (\%) } \\
\hline & 2 & 4 & 8 & 12 & 2 & 4 & 8 & 12 \\
\hline & \multicolumn{4}{|c|}{ (Weeks) } & \multicolumn{4}{|c|}{ (Weeks) } \\
\hline $28^{\circ} \mathrm{C}$ & $1.6 \pm 0.4$ & $9.5 \pm 1.4$ & $16.7 \pm 2.9$ & $23.3 \pm 3.2$ & 0 & 0 & 0 & 0 \\
\hline $32^{\circ} \mathrm{C}$ & $28.6 \pm 2.6$ & $31.8 \pm 3.4$ & $45.0 \pm 3.8$ & $51.6 \pm 4.1$ & 0 & 0 & 0 & 0 \\
\hline $36^{\circ} \mathrm{C}$ & $31.6 \pm 3.7$ & $39.5 \pm 4.0$ & $46.7 \pm 4.2$ & $55.0 \pm 4.3$ & $50 \pm 3$ & $65 \pm 4$ & $88 \pm 3$ & $88 \pm 2$ \\
\hline
\end{tabular}


(A) Muscle

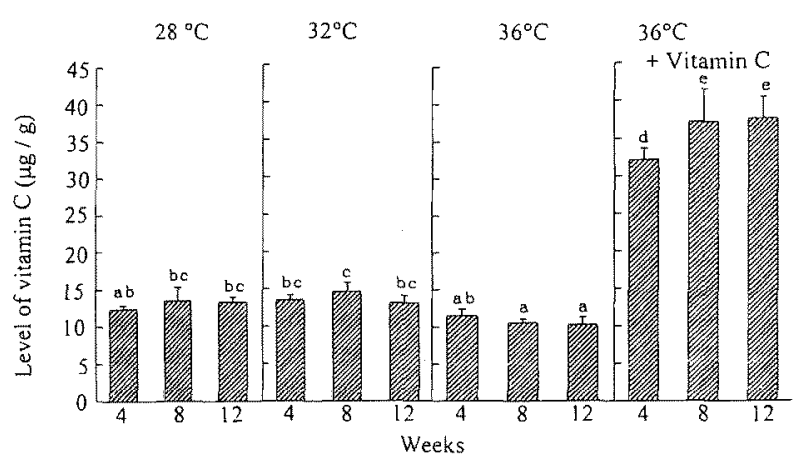

(B) Viscera

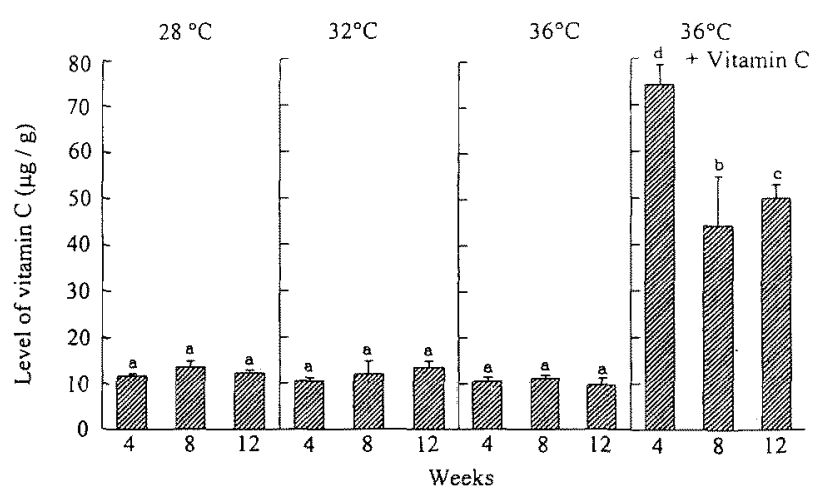

Fig. 4. The levels of vitamin $C$ in the muscle and viscera of thornfish separately cultured at different temperatures and fed diets with or without vitamin C-supplement for 12 weeks.

a-e: See footnote in Fig. 1.

yproline/proline in the skin and bone of thornfish in the $36^{\circ} \mathrm{C}$ group were lower than those of other groups. This indicated that the vitamin $\mathrm{C}$ requirement was insufficient for the growth of thornfish in thermal waters. Judging from the above data, thermal impact is supposed to cause the deficiency in vitamin $C$, and might be a factor responsible for the occurrence of deformed thornfish. This result is the same as the previous report. ${ }^{4)}$ The reason why the level of vitamin $\mathrm{C}$ in the liver of thornfish cultured at $36^{\circ} \mathrm{C}$ was not different from that of thornfish cultured at $28^{\circ} \mathrm{C}$ and $32^{\circ} \mathrm{C}$ is suspected to be associated with the optimal requirement of vitamin $C$ in different culture temperature, and is being studied now.

Acknowledgments The authors thank the Environmental Protection Administration and National Science Council, R.O.C. for their support of this project (NSC 84-2321-B-019-12).

\section{References}

1) L. S. Chen and K. T. Shao: Lethal temperatures of juvenile fish of waters in north-eastern Taiwan, in "Proceeding of fourth IUBS (International Union of Biological Science) International Symposium on Biomonitoring of the State of the Environment" (ed. By M. Yasuno and B. A. Whitton), Tokai University Press, Tokyo, Japan, pp. 5-10 (1987).

2) K. L. Fan: The thermal discharges from nuclear power plants in Taiwan. Chem. Ecol., 6, 213-224 (1992).

3) W. D. Chiou, L. Z. Cheng and H. C. Ou: Dispersion of thermal effluent at the Nuclear II Plant in northern Taiwan. J. Fish. Soc. Taiwan, 22, 69-82 (1995).

4) M. Sato, T. Kondo, R. Yoshinaka and S. Ikeda: Effect of water tem-
(A) Skin

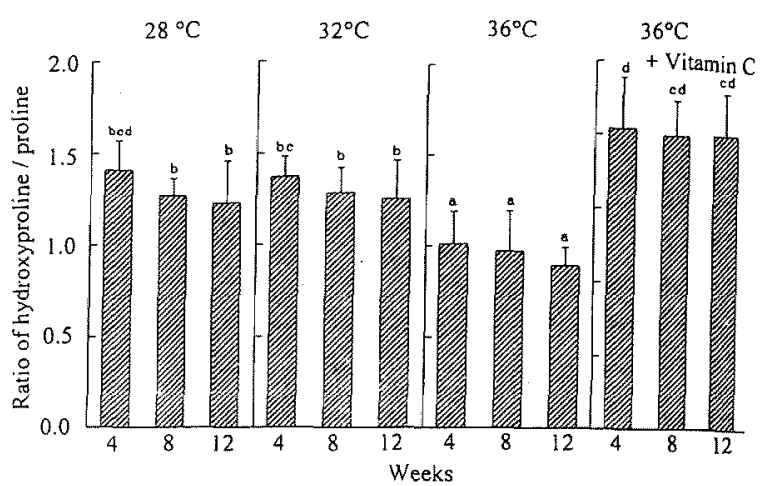

(B) Bone

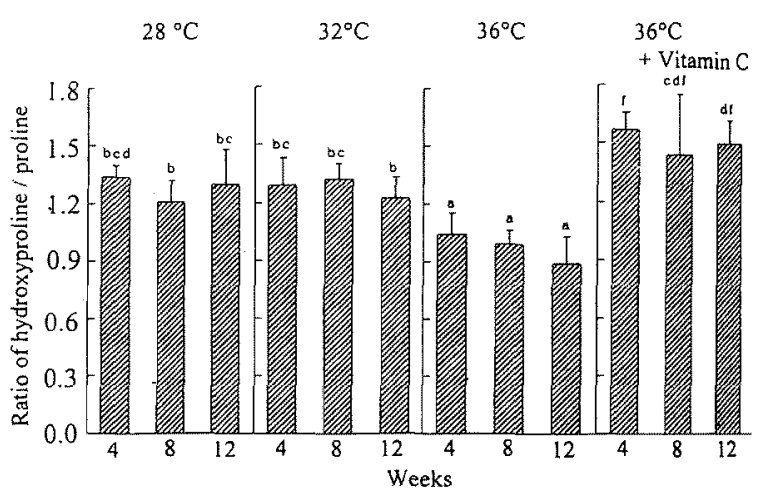

Fig. 5. The ratios of hydroxyproline/proline in the skin and bone of thornfish separately cultured at different temperatures and fed diets with or without vitamin C-supplement for 12 weeks.

a-f: See footnote in Fig. 1.

perature on the skeletal deformity in ascorbic acid-deficient rainfow trout. Nippon Suisan Gakkaishi, 49, 443-446 (1983).

5) E. Macconnell and F. T. Barrows: Pathological changes associated with vitamin $\mathrm{C}$ deficiency in walleyes. J. Aqu. Anim. Health, 5, 287-283 (1993).

6) M. J. Barnes and E. Kodicek: Biological hydroxylation and ascorbic acid with special regard to collagen metabolism. Vitam. Horm., 30, 1-43 (1972).

7) C. Lim and R. T. Lovell: Pathology of the vitamin C deficiency syndrome in channel catfish (Ictalurus punctatus). J. Nutr., 108, 11371146 (1978).

8) S. Y. Shiau and T. S. Hsu: Stability of ascorbic acid in shrimp feed during analysis. Nippon Suisan Gakkaishi, 59, 1535-1537 (1993).

9) R. Yoshinaka, M. Sato and S. Ikeda: Studies on collagenase in fishII. Some properties of a collagenase from the pyloric caeca of Serioa quinquerodiate. Nippon Suisan Gakkaishi, 42, 455-463 (1976).

10) W. Troll and J. Lindsky: A photometric method for the determination of proline. J. Biol. Fish., 215, 655-660 (1955).

11) Jr. Woesnner: The determination of hydroxyproline in tissue and protein samples containing small proportions of this imino acid. Arch. Biochem. Biophys., 93, 440-447 (1961).

12) K. Helrich: Official Methods of Analysis, 15th ed. A. O. A. C., New York, 1990, pp. 242-273.

13) S. C. Puri and K. Mukken: Multiple comparisons. In "Applied Statisties for Food and Agricultural Scientists" (ed. By G. K. Hall), Medical Publishers, Boston, MA, 1980, pp. 146-162.

14) M. C. Roger, B. Faessel and M. Lafont: Impact of warmed effluents of a nuclear power plant on benthic invertebrates in the river Rhone. Hydroecol. Appl., T3, 63-110 (1991).

15) G. Le-Feirre-Lehoerff, G. Grossel, D. Woehrling, J. M. Dewarumez and R. Delesmont: The nuclear power plant on the seashore at Gravelines: ecology, environment and impact. $J$. Rech. Oceanogr., 18, 33-38 (1993). 